\title{
Challenges Facing IASs/IFRS Implementation by Libyan Listed Companies
}

\author{
Shamsaddeen Faraj ${ }^{1, *}$, Essa El-Firjani ${ }^{2}$ \\ ${ }^{1}$ Gharyan Accounting Faculty, Al-Gabel Al-Garbi University \\ ${ }^{2}$ Department of Accounting, Tripoli University \\ *Corresponding Author: shamsaddeen1183@yahoo.com
}

Copyright (C) 2014 Horizon Research Publishing All rights reserved.

\begin{abstract}
This study examines the factors that may be considered as challenges or difficulties facing the implementation of the International Accounting Standards (IASs), and International Financial Reporting Standards (IFRS), by Libyan companies listed on the Libyan Stock Market (LSM). A qualitative approach was employed using semi-structured interviews to collect data. The results reveal that most listed companies prepare their financial statements taking into account the existing laws and the financial regulations, such as the Tax Law, and Libyan Commercial Law, prior to the GAAP with which they comply. The study also finds that the challenges facing the IASs/IFRS implementation in the preparation of listed companies' financial reports include the following: 1) most listed companies do not offer training programmes, and those that do have only weak provision in this respect, 2) accountants lack adequate skills, awareness and capabilities in implementing IASs/IFRS, 3) accounting education curricula do not include the IASs/IFRS on their syllabus, 4) the vast majority of participants are unable to use the English language in preparing accounts, 5) there is an absence of enforcement from the LSM and external auditors, and 6) the LSM governance mechanisms are weak.
\end{abstract}

Keywords Accounting Regulation, IASs/IFRS, Developing Countries, Libya, Listed Companies

\section{Introduction}

Over the years, corporations in developing countries have come to report their financial and accounting information according to the Generally Accepted Accounting Principles (GAAP) or their domestic accounting regulations. In this context, a key objective of accounting is to provide reliable information to stakeholders who may not have access to this information, to enable them to make rational decisions. However, [18] argues that as most stakeholders are remote from management, they are at an information disadvantage, and hence, there is information asymmetry. This information asymmetry is often used as a justification for accounting regulation. Consequently, a wide range of accounting regulations exist and influence the process of accounting and the work expected of accountants. As an example, there are accounting regulations and laws governing the operation of corporations, and many of these require the disclosure of reliable accounting information.

Accounting regulation, therefore, exists to minimise the remoteness gap created by the separation of management and ownership [23]. Therefore, the International Accounting Standards (IASs) or International Financial Reporting Standards (IFRS) are now used in almost every developed country as the reporting standards. For instance, the European Union adopted the IFRS as mandatory reporting standards for the consolidated financial reports of corporations listed on the European stock market [31]. Nowadays, the accounting profession and all interested parties, operate in an era of convergence from the GAAP to the IFRSs; although as found by [31] "some countries still use national GAAP as the basis of tax calculation and some countries adjust/change tax regulation to support IFRS implementation".

Implementation of these standards has been successful in emerging economies such as China, Zimbabwe, and Mauritius, but has failed in other countries such as Pakistan and Kuwait, [4]. This may be because the process of convergence is intensive, and presents a great challenge that may not be as simple as one may think [33]. From a review of the IFRS literature, it can be noted that IFRSs implementation in developed countries has received considerable attention from researchers $[13,17,22,26]$, However, this topic has been neglected in the developing country context. Hence, this paper aims to investigate the IFRSs implementation in developing countries, taking Libya as a typical developing North African country. More specifically, the study intends to investigate the factors that may be considered as challenges to IASs/IFRS implementation in Libya ${ }^{\mathrm{i}}$. The focus of the study is on Libyan listed companies, the reason being that these companies are mandated to prepare their financial reports according to the IASs/IFRS ${ }^{\text {ii }}$. 


\section{Literature Review}

The preference for either the IFRS or the US GAAP to operate as the internationally accepted uniform set of applications, is now less clear cut than previously, because while public opinion used to acknowledge the GAAP as the gold star, nowadays, as noted by [10], the world takes the IFRS as its reference point. In addition, from the perspective of professional accountants, compliance with the IFRS improves the comprehensibility and reliability of financial statements, and makes for a decrease in accounting frauds. Furthermore,[21, 35], argue that there is a convincing indication of the ability of these standards to enhance economic growth as their use attracts increased foreign investments.

Foreign investment within competitive and dynamic international capital markets, is driven in part by the presence of mandatory accounting standards for private companies in some developing Asian countries [8]. Moreover, [36] argue that the competitiveness and efficiency of the international capital market depend on the ability of financial statements preparers to communicate effectively with investors through the channel of financial reports. Therefore, it can be noted that preparing financial reports according to IFRSs may play a vital role in attracting foreign investment in developing countries. The implementation of the IFRSs in developing countries, does however, encounter certain challenges that may be considered to slow down the process of transition to IASs/IFRSs.

For instance, effectiveness in the application of the IFRSs in developing countries, requires human resources to be properly trained in order that the standards can be understood and applied. Currently, the absence of qualified personnel in this respect is a big challenge facing the process of transition to IFRS [2, 42, 19, 25]. In Nigeria, for example, it is found by [1], that two impediments to full implementation of the IFRS are the absence of training facilities, and the outmoded academic curriculum. Specifically, accounting education deficiencies and outdated accounting curricula serve to make the adoption of the IFRSs more difficult in that country [4, 25, 39], In this context, the lack of executive capacity, shortage of accounting personnel, and absence of suitable accounting infrastructure, can be attributed to accounting education shortcomings, all of which consequently obstruct companies in emerging economies in their efforts to make the transition to the IFRS [33,34], Another instance is that of Algeria, which like other developing countries suffers from a general lack of professional qualifications and practical experience amongst accounting educators. This problem represents a substantial challenge in the process of convergence to the IFRSs [38]. Another example is that of Libya, where accounting education and other educational programmes were established in the late 1950s according to models and advice from professional bodies and universities in the UK and the USA [28] Whilst this foundation was good at the time, since then the country's accounting profession has been struggling to move towards the application of the
IFRS due to the constraints of domestic laws and the overall regulatory framework.

In fact, a number of developing countries in Africa, which are affiliated to the British Commonwealth, have developed their accounting systems on the basis of the British Companies Acts [5], and clearly many of the socio-political, economic, cultural, and environmental considerations upon which these Acts were founded, are quite different from the particular economic circumstances prevailing in African countries. Therefore, one could argue that this legacy presents a big challenge to such countries as they plan to convert to the IFRSs. This point is articulated by [1] who state that:

"The IFRSs will lead to inconsistencies with existing laws such as the Companies and Allied Matters Act 1990, Securities and Exchange Commission laws, Banking laws and regulations and Insurance laws. Presently, the reporting requirements are governed by various regulators in Nigeria and their provisions override other laws. Whereas IFRS does not recognize such overriding laws, steps to amend these laws must be taken to ensure that the laws are amended well in time".

The adoption of the IASs/IFRSs can be observed as resulting from pressure brought to bear by external auditors. In Bahrain, for instance, external auditors are considered as a source of pressure on their clients as they strongly attempt to influence their decisions in favour of adopting the IASs $[3,24]$. Similarly, in Thailand local external auditors and Big 4 audit firms are perceived to exert pressure to persuade enterprises and corporations to adopt the IASs [41]. Moreover, in the Middle East countries, a number of national auditors have become partners with Big 4 audit firms and this has forced corporations to improve the level of reporting disclosure [32] Clearly, local external auditors, as partners with the Big 4 audit firms, facilitate the path towards adoption of the IFRS, although there does remain the need for local auditors to acquire proper communication skills, such as the English language.

The need to prepare financial reports in English is an important determinant of whether companies in countries where English language is not the native one adopt the IASs, as noted by [6], researching in the United Arab Emirates (UAE). For instance, countries with Anglo-Saxon ties are more likely than those without such ties, to adopt the IFRS as part of their corporate governance responsibility [9, 43], This is emphasised by [40], who state that "the Anglo-Saxon model [of governance] has been implanted on many developing countries due to colonial influence or pressure from international funding agencies". However, [30] argues that in the precise context of SMEs, it is the accounting culture of a certain geographical area that influences the application of the IFRS. In this context, Libya's accounting culture does not differ from those of Bahrain, United Arab Emirates and other Middle Eastern countries. More specifically, [37] argue that the auditing profession in Libya ${ }^{\text {iii }}$ is influenced by the cultural values of family, tribe, and community. And [42] provides support for this overall 
idea, pointing out that national cultures play a role in accountants' disclosure judgments and that uniform accounting standards may not result in similar disclosure decisions being made across countries. The review of the literature prompted the question of whether the above factors represent challenges to listed companies in Libya, and in order to shed light on this issue, data were collected using a qualitative approach. The following section describes and justifies the usage of this research method.

\section{Research Methodology and Data}

The research method adopted in this study is the semi-structured interview. The purpose of the interview is to provide valid and reliable data which are relevant to the objectives of the research study concerned [29]. It is accepted that the interview is the most widely employed method for data collection in qualitative research [11], and one reason is that interviews allow for more in-depth and insightful information about the topics under investigation to be obtained. Whilst the use of interviews can be time-consuming, when the population involved is relatively small, as is the case in this study, interviews can be very effective. The designing and structure of data collection technique comprised of three sections. Section one covers the biographic data about the participant, while section two consists of open ended questions that reveal the way they carry out their accounting entries. The third section is designed to uncover if there is any challenges or barriers that may prevent the application of IASs/IFRS. This study's population comprises all financial managers and internal auditors in charge of all ten Libyan companies listed on the LSM. This produces a total of 20 subjects, three of whom were unwilling to participate, and six of whom were not available. The eventual interviewee group therefore comprised eleven subjects.

\section{Findings and Discussions}

The results of the semi-structured interviewees are presented in Table 1. When interviewees were asked on what basis they prepared financial statements, they all indicated that their companies were following the GAAP. For instance, one of the internal auditors said “our company's financial statements are prepared according to the GAAP which I have had studied during my graduate school, despite the company is registered in the Libyan stock market". Similarly, one financial manager added "the financial statements of the company are prepared in accordance with the GAAP, and I think these financial statements are produced according to the IASs because the IASs do not differ from the GAAP".

Table 1. Challenges Facing IASs/IFRS Implementation By Libyan Listed Companies

\begin{tabular}{|c|c|c|c|c|c|c|c|c|c|c|c|c|c|c|c|}
\hline Participants & A & B & $\mathrm{C}$ & $\mathrm{D}$ & E & $\mathrm{F}$ & G & $\mathrm{H}$ & I & $\mathrm{J}$ & K & L & M & $\mathrm{N}$ & 0 \\
\hline FM & $\sqrt{ }$ & & $\sqrt{ }$ & $\sqrt{ }$ & & & & $\sqrt{ }$ & $\sqrt{ }$ & $\sqrt{ }$ & $\sqrt{ }$ & $\sqrt{ }$ & $\sqrt{ }$ & & $\sqrt{ }$ \\
\hline FM & $\sqrt{ }$ & & $\sqrt{ }$ & $\sqrt{ }$ & $\sqrt{ }$ & & & $\sqrt{ }$ & $\sqrt{ }$ & $\sqrt{ }$ & $\sqrt{ }$ & & $\sqrt{ }$ & & $\sqrt{ }$ \\
\hline FM & $\sqrt{ }$ & & $\sqrt{ }$ & $\sqrt{ }$ & $\sqrt{ }$ & & & $\sqrt{ }$ & $\sqrt{ }$ & $\sqrt{ }$ & $\sqrt{ }$ & & $\sqrt{ }$ & & $\sqrt{ }$ \\
\hline FM & $\sqrt{ }$ & & $\sqrt{ }$ & $\sqrt{ }$ & & & & $\sqrt{ }$ & $\sqrt{ }$ & $\sqrt{ }$ & $\sqrt{ }$ & & $\sqrt{ }$ & & $\sqrt{ }$ \\
\hline FM & $\sqrt{ }$ & & $\sqrt{ }$ & $\sqrt{ }$ & & & & $\sqrt{ }$ & $\sqrt{ }$ & $\sqrt{ }$ & $\sqrt{ }$ & & $\sqrt{ }$ & & $\sqrt{ }$ \\
\hline FM & $\sqrt{ }$ & & $\sqrt{ }$ & $\sqrt{ }$ & $\sqrt{ }$ & & & $\sqrt{ }$ & $\sqrt{ }$ & $\sqrt{ }$ & $\sqrt{ }$ & & $\sqrt{ }$ & & $\sqrt{ }$ \\
\hline InA & $\sqrt{ }$ & & $\sqrt{ }$ & $\sqrt{ }$ & $\sqrt{ }$ & & & $\sqrt{ }$ & $\sqrt{ }$ & $\sqrt{ }$ & $\sqrt{ }$ & & $\sqrt{ }$ & & $\sqrt{ }$ \\
\hline InA & $\sqrt{ }$ & & $\sqrt{ }$ & $\sqrt{ }$ & $\sqrt{ }$ & & & $\sqrt{ }$ & $\sqrt{ }$ & $\sqrt{ }$ & $\sqrt{ }$ & & $\sqrt{ }$ & & $\sqrt{ }$ \\
\hline InA & $\sqrt{ }$ & & $\sqrt{ }$ & $\sqrt{ }$ & $\sqrt{ }$ & & & $\sqrt{ }$ & $\sqrt{ }$ & $\sqrt{ }$ & $\sqrt{ }$ & $\sqrt{ }$ & $\sqrt{ }$ & & $\sqrt{ }$ \\
\hline InA & $\sqrt{ }$ & & $\sqrt{ }$ & $\sqrt{ }$ & & & & $\sqrt{ }$ & $\sqrt{ }$ & $\sqrt{ }$ & $\sqrt{ }$ & & $\sqrt{ }$ & & $\sqrt{ }$ \\
\hline InA & $\sqrt{ }$ & & $\sqrt{ }$ & $\sqrt{ }$ & $\sqrt{ }$ & & & $\sqrt{ }$ & $\sqrt{ }$ & $\sqrt{ }$ & $\sqrt{ }$ & $\sqrt{ }$ & $\sqrt{ }$ & & $\sqrt{ }$ \\
\hline \multicolumn{16}{|c|}{ Total $=11$ Interviewees } \\
\hline
\end{tabular}

$\mathrm{A}=$ accounts prepared according to GAAP, $\mathrm{B}=$ accounts prepared according to IAS/IFRS, $\mathrm{C}=$ accounts preparation influenced by laws, $\mathrm{D}=$ existing laws considered prior to GAAP, $\mathrm{E}=$ existing laws limit the application of IAS/IFRS, $\mathrm{F}=$ accounts produced in English, $\mathrm{G}=$ laws require English use, $\mathrm{H}=$ accounting education deficiencies affect IAS/IFRS application, I = lack of training affects IAS/IFRS application, J = lack of expertise affects IAS/IFRS application, $\mathrm{K}=$ unawareness of IAS/IFRS limits its application, $\mathrm{L}=$ availability of IAS/IFRS text book, $\mathrm{M}=$ financial statements in English more beneficial than those in Arabic, $\mathrm{N}=$ external auditor requires compliance to IAS/IFRS, $\mathrm{O}=$ financial statements prepared according to IAS/IFRS would provide more reliable information than those prepared according to GAAP. 
As for the existing laws and regulations relating to the preparation of companies' financial statements, all interviewees stated that they took certain laws and financial regulations into account when preparing these accounts. For example, one internal auditor said that "the laws and financial regulations which are followed when companies prepare their accounts such as Tax Law (TL), Commercial Law (CL), General Financial regulation (GFR), and Company's Internal Regulations (CIR)". Another financial manager stated that "there some laws and financial regulations are imposed on companies and must be followed when preparing the financial statements which are namely TL, CL, GFR and CIR".

With regard to the source of influence of both existing laws and the GAAP, all interviewees stated that the laws and financial regulations are applied prior to the GAAP. For example, one manager said that "in fact, we consider the laws and regulations which are compulsory to implement by the company, especially those articles that are relevant to the accounting treatments, and then we follow the GAAP for accounting treatments that are not included in these laws".

Almost $60 \%$ of respondents expressed the opinion that the existing laws and financial regulations limited the application of the GAAP and/or IASs. For instance, one financial manager said "there is a flexibility in the application of any accounting standards such as IASs or the GAAP. But the company must apply the laws and financial regulation before these accounting standards". As for using the English language in preparing financial statements, all respondents confirmed that English was not used in their companies at all. Furthermore, there is no law in Libya that requires companies to use English language in preparing accounts.

These results revealed that the Libyan listed companies prepare their accounts according to the GAAP, and that the financial statements are strongly influenced by the laws and financial regulations of the country, which are adhered to prior to the GAAP. Moreover, the results are consistent with those of previous studies [1,5] which revealed that the existing laws are not in line with the IFRS, and that IFRS implementation requires amendments to these statutes. In the context of Libya, it can be concluded that Libyan authorities adopted IASs in 2006 without any alteration to the prevailing legislation, and the lack of change in this respect, is considered a big challenge facing IASs implementation.

When interviewees were asked about the difficulties encountered in attempting to implement the IASs/IFRS when preparing listed companies' financial statements, they all confirmed that the companies concerned did not actually apply the IASs/IFRS because of the problems they faced in trying to do that. Essentially, the problems refer to the fact that accountants are unaware of IRSs/IFRS applications, and incapable of compliance as there are no relevant training programmes to educate them in this matter. Consequently, accountants remain ignorant. One internal auditor said "I think that all accountants and internal auditors in our company have neither efficiency nor the ability to follow
IASs/IFRS when they prepare company's accounts. Moreover, they have no idea about these standards at all, and there is not any source of IASs/IFRS reference available so that they can get more information about these standards. I also believe that if accountants in financial departments and internal auditors are provided with suitable and adequate training programmes about IASs/IFRS applications, they would have the efficiency and skills so that they would be able to apply IASs/IFRS".

The shortcoming in accounting education curricula, already mentioned, and evident in the fact that there is no coverage of the IASs/IFRS, is the reason why accountants are deficient in this respect. Without the fundamental knowledge of the IASs/IFRS in the first place, accountants cannot be expected to prepare financial statements in accordance with these standards. On this issue, one financial manager said "I believe that inadequate accounting education in Libya is considered as one of the reasons behind companies not able to apply IASs/IFRS. This is because the accounting education curriculums do not include IASs/IFRS programmes, except the postgraduate programmes which include a limited introduction of IAS. In addition, the senior management of the company does not pay attention about these standards". That said, however, the fact that the English language is not used as an official language in Libya means that even with an improved accounting curriculum, accountants would be unable to produce financial statements in English. Indeed, the lack of ability in English language has made it difficult for accountants to understand even the translated version of the IASs/IFRS. Clearly, these factors represent large obstacles to the application of these standards in Libya.

They are not, however, the only problems since another barrier is seen in the lack of enforcement by external auditors, the Libyan Accounting Bureau (LAB), and the Libyan Stock Market (LSM). This was confirmed by one internal auditor who said "there is no any enforcement imposed from the external auditors or the LSM to implement IASs/IFRS. Although, the LSM requires all listed companies to follow IASs in preparing the financial statements, LSM lacks the pressure to impose its authority upon listed companies to apply IASs. Furthermore, even other related governing parties do not have any enforcement on the implementation of IASs".

When interviewees were asked about the role of external auditors in exercising pressure or providing advice to facilitate the implementation of the IASs in preparing financial statements, all respondents emphasised that audit reports include the financial statements representing their companies' financial positions, and that these are prepared according to the GAAP without reference to the IASs, despite the fact that the LSM law requires companies to follow the IASs.

Obviously, the application of the IASs/IFRS faces several difficulties, which can be listed as: the lack of training programmes; the lack of inclusion in the accounting curriculum of the IASs; the consequent lack of awareness 
among preparers of the IASs/IFRS and how to implement them; the absence of enforcement; the weakness of the LSM governance system; and the inability of preparers and auditors to use the English Language. These findings are in line with those of $[1,4,6,9,25,28,39]$. However, these results are inconsistent with the results of $[3,24,32,41]$, since all these researchers found that external auditors do exercise pressure to try to achieve IASs implementation. From these findings, one can conclude that the difficulties preventing listed companies from applying the IASs/IFRS are due to the fact that the English Language is not used since this has led to the lack of awareness of the standards among preparers and auditors.

\section{Conclusions}

This study aimed to examine the challenges facing Libyan listed companies in their application of the IASs/IFRS. The interviewees revealed that although the LSM law requires compliance with the IFRS, listed companies prepare their financial statements considering the existing laws and the financial regulations (such as the TL and LCL), prior to the GAAP. Several challenges to the process of implementing the IASs/IFRS in preparing financial statements were highlighted, these being: the lack of training programmes; the lack of inclusion in the accounting curriculum of the IASs; the consequent lack of awareness among preparers of the IASs/IFRS and how to implement them; the absence of enforcement; the weakness of the LSM governance system; and the inability of preparers and auditors to use the English Language. Given these results, it is recommended that Libyan regulators amend the existing laws to facilitate IASs/IFRS applications. Policy-makers also need to incorporate these standards into accounting curriculums and training programmes to ensure that there is synchronisation between the accounting profession, and accounting education at the national level. One limitation to this research is that this study does not include the opinion of external auditors because it is expected that they would provide defensive opinion about their role of enforcement towards the application of IASs/IFRS. However, future research to include the views of external auditors would explain more about the level of acquiescence on application of IASs/IFRS. It would also be appropriate to conduct more research to explore whether such challenges exist in the Libyan banking sector, and to assess the current state of corporate governance in Libyan companies generally.

\section{REFERENCES}

[1] Ailemen, I. O. and Akande, A. O. (2012) "International Financial Reporting Standards (IFRS): Benefits, Obstacles and Intrigues for Implementation in Nigeria", Business Intelligence Journal, Vol.5 No.2, pp. 299 - 307.
[2] Akdogan, N. (2007) "Accounting in Turkey/Financial Reporting Standards Application Process: Problems, Solutions", Journal of Financial Solutions, Vol. 80, pp. 101 117.

[3] Al-Basteki, H. (1995) "The Voluntary Adoption of International Accounting Standards by Bahrain Corporations", Advances in International Accounting, Vol. 8, pp. 47-64.

[4] Albu, N. and Albu, C. N. (2012) "International Financial Reporting Standards in an Emarging Economy: Lessons from Romania", Australian Accounting Review, Vol. 22, No. 63, pp. $341-352$.

[5] Alexander, D. and Nobes, C. (2010) "Financial Accounting: An International Introduction" 4th. London, Prentice Hall.

[6] Aljifri, K. and Khasharmeh, H. (2006) "An Investigation into the Suitability of the International Accounting Standards to the United Arab Emirates Environment", International Business Review, Vol. 15, pp. 505 - 526.

[7] Bait-El-Mal, M.M., Smith, C.H. and Taylor, M.E. (1973) "The Development of Accounting in Libya", International Journal of Accounting, 8(spring), pp. 83-101.

[8] Bhatia, S. (2012) "Private Company Accounting Drivers in Asia", 2nd Annual International Conference on Accounting and Finance, Procedia Economics and Finance, Vol. 2 pp, 116 -124 .

[9] Boolaky, P.K. (2012) "Accounting Development and International Financial Reporting Standards in Small Island Economies: The Case of Mauritius between 1960-2008". Journal of Accounting in Emerging Economies, Vol. 2.No. 1, pp. 4-29.

[10] .Bozkurt, O., Islamoğlu, M., and Oz, Y. (2013) "Perceptions of Professionals Interested in Accounting and Auditing about Acceptance and Adaptation of Global Financial Reporting Standards", Journal of Economics, Finance and Administrative Science, Vol.18, No. 34, pp, 16-23.

[11] Bryman, A. (2004) "Social Research Methods", 2nd, ed, Oxford, New York.

[12] Central Bank of Libya (2005) "Banking Law No. 1 of 2005". Tripoli. Libya.

[13] DeFond, M., Hu, X., Hung, M., Li, S. (2011) "The impact of mandatory IFRS adoption on foreign mutual fund ownership: The role of comparability", Journal of Accounting and Economics, Vol.51, No, 3, pp 240-258.

[14] Dempsey, M. (2013) "Libya in Transition; Reforming the Financial Sector to Spur Economic Growth", Legatum Institute \& Brehon Advisory. November, 2013, pp. 1 - 19.

[15] Elfirjani, E. (2010) "Investigating the Corporate Accounting Regulation and Factors Influencing the Adoption of International Accounting Standards (IAS) in Libya" unpublished Thesis, Liverpool John Moores University UK.

[16] Faraj, S. Akbar, S. (2010) "An empirical investigation of the Libyan audit market: perceptions of auditor's independence", Journal for Global Business Advancement, Vol. 3 No.2, pp.133-154.

[17] Florou, A., Pope, P.F. (2012) "Mandatory IFRS Adoption and Institutional Investment Decisions". The Accounting Review, Vol. 87, No. 6, pp. 1993-2025. 
[18] Gaffikin, M.J.R. (2005) "Regulation as Accounting Theory", Accounting \& Finance working paper 05/09, School of Accounting \& Finance, University of Wollongong, Research Online.

[19] Gonen, S., Ugurluel, G. (2007) “Turkey, International Financial Reporting Standards (IFRS) Transition Challenges Facing Applications and Solutions", Journal of World Tax, Vol. 316, pp. $229-236$.

[20] GPC (2006) "General People Committee Initiative No. 134/2006 regarding the Establishment of Libyan Stock Market and its Executive Guidelines"

[21] Hove, M. (1989) "The inappropriateness of international accounting standards in less developing countries: The case of international accounting standard number 24 -Related Party Disclosure -concerning transfer prices", The International Journal of Accounting Education and Research, Vol. 24, No. 2, pp. 81-100.

[22] Jeanjean, T., Stolowy, H. (2008) "Do Accounting Standards Matter? An Exploratory Analysis of Earning Management before and after IFRS Adoption", Journal of Accounting and Public Policy, Vol. 27, No.6, pp 480-494.

[23] Jensen, M.C. and Meckling, W.H. (1976) "Theory of the Firm: Managerial Behaviour, Agency Costs, and Ownership Structure", Journal of Finacial Economics, Vol. 3.4, pp. 305-360.

[24] Joshi, P. L. and Ramadhan, S. (2002) "The Adoption of International Accounting Standards by Small and Closely Held Companies: Evidence from Bahrain", The International Journal of Accounting, Vol. 37, pp. $429-440$.

[25] Kapoor, B, and Ruhela, J. (2013) "IFRS Implementation Issues and Challenges for India", International Journal of Business and Management Research, Vol. 3, No. 2, pp. 103 106.

[26] Landsman, W.R., Maydew, E.L., Thornock, J.R (2012) “The information content of annual earnings announcements and mandatory adoption of IFRS", Journal of Accounting and Economics, Volume. 53, No 1-2, pp. 34-54.

[27] Libyan Accountants \& Auditor Association's Law 116 (1973) "Regarding the Organisation of Accounting and Auditing Profession in Libya", The Official Gazette, Libya.

[28] Mahmud, M.B. \& Russell, A. (2003) "An empirical investigation of the development of accounting education and practice in Libya, and of strategies for enhancing accounting education and accounting practice in Libya", Research in Accounting in Emerging Economies, Vol. 5, pp.197-236.

[29] Marchall, C. and Rossman, G. (1989) "Designing Qualitative Research", Sage Publications.

[30] Masca, E. (2012) "Influence of Cultural Factors in Adoption of the IFRS for SMEs", Procedia Economics and Finance,

\footnotetext{
i Libya's accounting profession is oriented towards the accounting systems of UK and USA. It has followed the General Accepted Accounting Principles (GAAP) (Bait-El-Mal et al, 1973; Mahmud and Russell, 2003). Recently, Libya is in a transitional phase to liberalise the economy though this attempt has faltered and discouraged investment due to high level of uncertainty, which can be attributed to many reasons some of which is lack of corporate governance practise, Dempsey (2013). Libyan government
}

Vol, 3, pp. $567-575$.

[31] Mulyadi, M.S., Soepriyanto, G., Anwar, Y. (2012) "IFRS adoption and taxation issue", International Journal of Arts and Commerce, Vol. 1, No. 7, pp. 159-165.

[32] Naser, K. and Nuseibeh, R. (2003) "Quality of Financial Reporting: Evidence from the Listed Saudi nonfinancial Companies", The International Journal of Accounting, Vol. 38, PP. 41-69.

[33] Nwachukwu, I. (2012) "KPGM Identifies Challenges Facing Companies Adopting IFRS", Available at http://businessdayonline.com/NG/index.php/markets/compa nies-and-market/46065-kpgm-identifies-challenges-facing-c ompanies-adopting-ifrs? format=pdf.

[34] Okaro S. C. (2011) "International Financial Reporting Standards - An Emerging Market Perspective", Social Science Research Network.

[35] Perera, M.H.B. (1989) "Accounting in developing countries; a case for localized uniformity", British Accounting Review, Vol. 21, pp. $141-158$.

[36] Rezaee, Z., Smith, L.M., Szendi, J.Z. (2010) "Convergence in accounting standards: Insights from academicians and practitioners", Advances In Accounting, Vol. 26, No. 1, pp. $142-154$.

[37] Ritchie, B. \& Khorwatt, E. (2007) "The Attitude of Libyan Auditors to Inherent Control Risk Assessment", British Accounting Review, Vol. 39, No. 1, pp. 39-59.

[38] Saidi, F. (2013) “Accounting Developments in Algeria: The Road to IFRS", International Research Journal of Applied Finance. Vol. IV, pp. 124-142.

[39] Schachler, M. H, Al- Abiyad, S. A, Al- Hadad, A. A. (2012) "Evaluation of the Suitability of International Financial Reporting Standards (IFRSs) for Application in Emerging North African Countries: A literature Review and a Research Agenda", Journal of Modern Accounting and Auditing, Vol. 8, No. 12, pp. $1773-1779$.

[40] Senaratne, S. and Gunaratne, P. S. M. (2008) "Corporate Governance Development in Sir Lanka; Prospects and Problems", International Research Conference and Management and Finance, University of Colombo.

[41] Srijunpetch, S. (2004) "The Implementation of International Accounting Standards in Thailand", Unpublished PhD Thesis, the University of Manchester, UK.

[42] Tsakumis, G.T. (2007) "The Influence of Culture on Accountants' Application of Financial Reporting Rules", Abacus, Vol. 43, No. 1, pp. 27-48.

[43] Zeghal, D. and Mhedhbi, K. (2006) "An Analysis of the Factors Affecting the Adoption of International Accounting Standards by Developing Countries", The International Journal of Accounting, Vol. 41, pp. $373-386$.

enacted the banking Law No. 1 of 2005 that governs the banking sector, and Libyan Stock Market initiative (LSM) No. 134 of (2006) which established the LSM, then amended by the initiative No. 436 of 2008 . Moreover, the Libyan government enacted Law No. 11 of (2010) that governs the activity of LSM and the listed companies. These laws require all banks and listed companies to pursue IASs. However, (Elfirjani 2010) reports that listed Libyan companies still comply with the GAAP. Moreover, the corporate accounting regulation in Libya has been influenced by many laws such as the Libyan Tax Law No. 7 of 2010, the Libyan Commercial Law No. 23 of 
2010, and the General Financial Regulation (GFR) of 1980.

Although Libyan government mandated the adoption of IASs/IFRS, these standards have not been translated into Arabic language nor introduced into the accounting curriculum. However Libyan accountants carry out the accounting entries applying the GAAP, which were translated into Arabic language more than four decades ago. Thus the GAAP is taught amongst accounting curriculum in the country.

ii Libya's audit market consists of large local auditors, small audit offices and Big 4 audit firms, for instance Ernst and Young, PWC, KPMG and Deloitte all have their offices in Tripoli (Faraj and Akbar, 2010). 